\title{
Gender and Start-Up Capital for Agrifood MSMEs in Indonesia and Viet Nam
}

Kate Ambler, Alan de Brauw, Sylvan Herskowitz, and Mike Murphy

Micro, small, and medium enterprises (MSMEs) in developing countries frequently face financial constraints undermining their ability to reach their full production potential. These constraints include exposure to uninsured risk, lack of suitable savings technologies, and expensive or inaccessible credit. Such challenges may be particularly acute for MSMEs operating in the agrifood system, in value chains between farmers and retailers, where the seasonality and structure of these value chains creates unique financing needs relative to other sectors. Moreover, constraints affecting MSME performance in one part of the value chain may impact other value chain actors both up and downstream, including smallholder farmers, consumers, and exporters. As has been observed more broadly about MSMEs, marginalized groups such as women, low-income households, and ethnic minorities often face additional barriers to finance and adoption suitable financial services. ${ }^{1}$ If so, then the most vulnerable populations may be unintentionally excluded from emerging economic opportunities in the agriculture sector.

These constraints remain an issue even in the fast-growing economies of Southeast Asia. Despite proximity to some of the world's largest consumer markets, research shows that a large proportion of longterm credit needs for actors in the agrifood system in Southeast Asia are not being met (Shakhovskoy \& Wendle, 2013). Where agricultural opportunities should be abundant, limited access to liquidity poses particular challenges for MSMEs presented with products poorly aligned with the needs of the agrifood sector, limited overall availability of affordable credit, and prohibitive eligibility requirements for borrowing.

A major challenge for documenting these constraints is that existing data is limited on MSMEs both in general and in countries in Southeast Asia in particular. Available nationally representative data provide limited detail on business structure, ownership and management responsibilities, and the full set of financial needs and service usage that would be needed for a rich characterization of these dynamics. Data would ideally give a clear indication of broad constraints against obtaining credit or other financial services, while documenting how constraints differentially affect women and other marginalized groups. Complete gender disaggregation across these dimensions is frequently missing, and data on relevant measures is aggregated to either the household or firm level. Improved observational data could provide 
a clearer and more nuanced picture of the state of MSME businesses and constraints faced by women and other marginalized groups.

In this note, we use business level data from the World Bank's Enterprise Surveys (WBES) conducted in 2015 and household-level data from the 2015 Indonesian Family Life Survey (IFLS) and the 2016 Viet Nam Access to Resources Household Survey (VARHS) to characterize financial constraints faced by MSMEs owned by men and women in Southeast Asia. First, we consider the WBES data sets, which are designed to be nationally representative surveys of firms with at least five employees, and we analyze basic statistics on businesses in all sectors versus those in the food sector. Table 1 shows that in general, bank usage by firms is relatively low in both countries, which likely reflects problems with access to banks. In both Indonesia and Viet Nam, the percent of firms with bank accounts is low relative to the regional East Asia and the Pacific average, whether firms are in the food sector or not. Usage of bank loans is somewhat lower in Indonesia (29\%) than Viet Nam (45\%) in the food sector than overall averages; however, in both countries loans almost always require collateral. Moreover, in both countries the value of collateral must exceed the loan value in the food sector by 2.7 times, whereas in all sectors the value or required collateral is lower. Businesses in the food sector are also more likely than others to report needing a loan, although firms in Viet Nam are much more likely to actually use financing from banks for investments (43\%) than those in Indonesia (7.5\%).

\section{Table 1: Business Bank Usage in Food and Non-food Sector, Indonesia and Viet Nam}

\begin{tabular}{|c|c|c|c|c|c|}
\hline & \multicolumn{2}{|c|}{$\begin{array}{c}\text { Indonesia } \\
N=1,320\end{array}$} & \multicolumn{2}{|c|}{$\begin{array}{c}\text { Viet Nam } \\
N=996\end{array}$} & \multirow{2}{*}{$\begin{array}{l}\text { East Asia } \\
\text { \& Pacific } \\
\text { All sectors }\end{array}$} \\
\hline & All sectors & Food & All sectors & Food & \\
\hline Percent of firms with a checking or savings account & 59.8 & 61.4 & 55.8 & 34.8 & 81.5 \\
\hline Percent of firms with a bank loan/line of credit & 27.4 & 27.8 & 40.8 & 44.8 & 33.7 \\
\hline Proportion of loans requiring collateral (\%) & 80.4 & 92.6 & 91 & 93.4 & 82.3 \\
\hline Value of collateral needed for a loan (\% of the loan amt) & 241.1 & 271.2 & 216 & 271.1 & 229.7 \\
\hline Percent of firms not needing a loan & 42.8 & 32.5 & 50 & 45.5 & 48.5 \\
\hline Percent of firms using banks to finance investments & 36.6 & 7.5 & 29.3 & 42.7 & 25.1 \\
\hline Proportion of investment financed internally (\%) & 66 & 34.2 & 67.3 & 56.7 & 72.1 \\
\hline Proportion of investment financed by banks (\%) & 12.8 & 1.5 & 15.4 & 32.7 & 14.6 \\
\hline Percent of firms using banks to finance working capital & 32 & 30.4 & 32.3 & 47 & 28.5 \\
\hline Proportion of working capital financed by banks (\%) & 9.9 & 6.3 & 13.1 & 26.7 & 12.8 \\
\hline
\end{tabular}

Source: World Bank Enterprise Surveys (2015).

The business-level statistics suggest the food sector may be disadvantaged in its access to financing, and relative to regional averages there is room for improvement. The larger and more formal firms in the WBES play an important role in the private sector economy, however, and they may differ from micro and household level enterprises. To examine financing needs and gaps of micro-enterprises, we switch 
to household level data and examine the relationship of non-farm businesses to formal sources of finance, as reported in the IFLS and VARHS.

Table 2 shows that a large share of households report having a non-farm business in these two countries: $36 \%$ in Indonesia and $29 \%$ in Viet Nam. In turn, many of these businesses can be linked to the agrifood system, accounting for $43 \%$ of businesses in Indonesia and $32 \%$ in Viet Nam. On average, businesses in Indonesia use 82 USD of start-up capital while those in Vietnam use substantially more, 440 USD. ${ }^{2}$ Savings and self-financing are the primary modes of generating this startup capital. Control of these businesses is evenly split by gender, with roughly equal shares controlled by men and women in both countries. However, these summary statistics mask meaningful differences in these businesses by gender of the business owner.

Table 2: Business Background in Indonesia and Viet Nam

\begin{tabular}{lllll} 
& \multicolumn{2}{c}{ Indonesia } & Viet Nam \\
& Average & $N$ & Average & 2781 \\
\hline Households reporting a non-farm business & 0.36 & 15921 & 0.29 & 813 \\
\hline Sector: Agricultural business & 0.02 & 6480 & 0.05 & 813 \\
Sector: Restaurant/Food service & 0.34 & 6480 & 0.09 & 813 \\
\hline Sector: Food industry & 0.07 & 6480 & 0.17 & 813 \\
\hline Median start-up capital (USD) & 82.2 & 5862 & 440.0 & 813 \\
\hline Male business & 0.37 & 6480 & 0.49 & 813 \\
\hline Female business & 0.36 & 6480 & 0.51 & - \\
\hline Male \& female business & 0.27 & 6480 & & - \\
\hline
\end{tabular}

Note: Non-farm businesses include all non-agricultural self-employment activities.

Sources: IFLS (2015) for Indonesia and VARHS (2016) for Viet Nam.

Table 3 shows some key statistics related to business ownership by gender in both countries. ${ }^{3}$ First, we see that female-owned businesses are more likely to be based at home, suggesting lower investments in operating space. Women's disproportionate childcare and home management responsibilities may hinder both their available labor contributions as well as mobility; these factors could impede the scale, growth potential, and profitability of their businesses. Additionally, reported start-up capital is five times greater for male-owned businesses than those controlled by women in both countries. 


\section{Table 3: Business Background by Gender, Indonesia and Viet Nam}

\begin{tabular}{|c|c|c|c|c|c|c|c|c|}
\hline & \multicolumn{4}{|c|}{ Indonesia } & \multicolumn{4}{|c|}{ Viet Nam } \\
\hline & \multicolumn{2}{|c|}{ Male businesses } & \multicolumn{2}{|c|}{ Female businesses } & \multicolumn{2}{|c|}{ Male businesses } & \multicolumn{2}{|c|}{ Female businesses } \\
\hline & Average & $\mathrm{N}$ & Average & $\mathrm{N}$ & Average & $\mathrm{N}$ & Average & $\mathrm{N}$ \\
\hline Business is based at home & 0.16 & 2395 & 0.37 & 2324 & 0.51 & 395 & 0.61 & 416 \\
\hline Start-up capital [USD] & 205.58 & 2103 & 41.12 & 2092 & 1320.00 & 395 & 220.00 & 416 \\
\hline Sector: Agriculture business & 0.03 & 2395 & 0.01 & 2324 & 0.08 & 395 & 0.03 & 416 \\
\hline Sector: Food services & 0.16 & 2395 & 0.45 & 2324 & 0.05 & 395 & 0.13 & 416 \\
\hline Sector: Food industry & 0.03 & 2395 & 0.10 & 2324 & 0.12 & 395 & 0.22 & 416 \\
\hline
\end{tabular}

Note: Male and female designation reflects ownership.

Sources: IFLS (2015) for Indonesia and VARHS (2016) for Viet Nam.

Next, we see that women are more likely to run food related businesses. Three times as many femaleowned businesses as male-owned businesses are in food services or food industry in Indonesia and roughly twice as many in Vietnam. By contrast, men are three times more likely to own an agriculturelinked non-farm businesses, although the overall incidence of these businesses is very low (2\% in Indonesia and $5 \%$ in Vietnam).

This selection into different business sectors also influences the capital needs of new businesses. Figure 1 shows that non-food businesses are reported to have substantially higher start-up capital in both countries. With women over-represented in food related businesses, part of the gap in start-up capital can be explained: women are more likely to participate in these low-startup capital ventures.

\section{Figure 1: Start-up Capital by Business Types, Indonesia and Viet Nam}

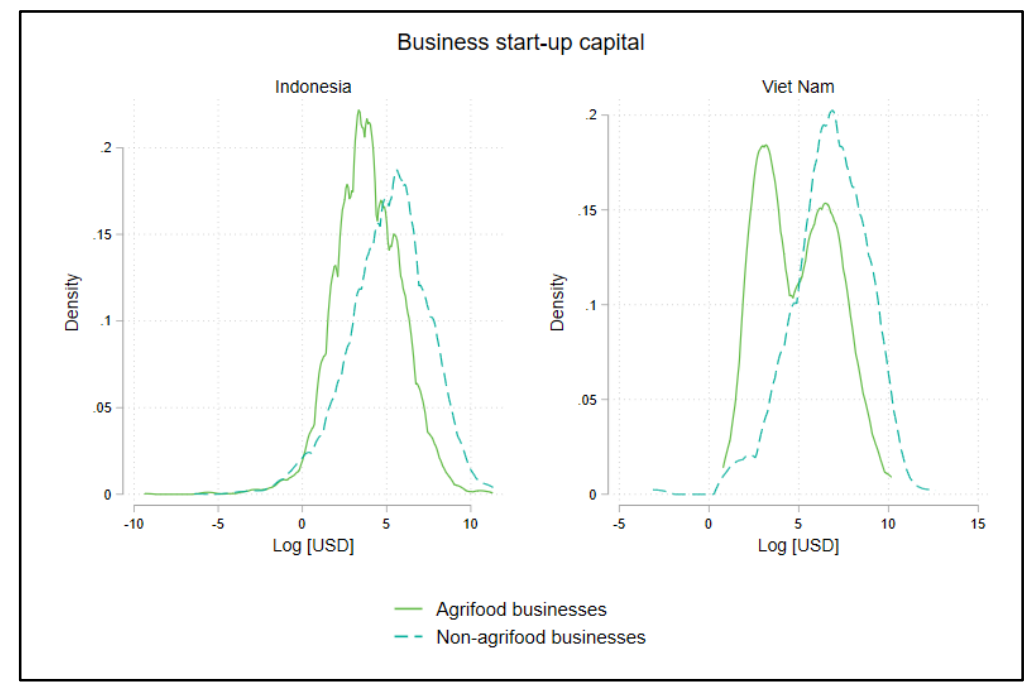


However, choice of business type cannot fully explain the gender gap in start-up financing. Figure 2 shows densities of start-up capital in the two countries by business types and by gender. In both countries women's start-up capital was substantially lower than those of men with the same type of business.

Figure 2: Start Up Capital Within Agrifood Industry by Gender, Indonesia and Viet Nam

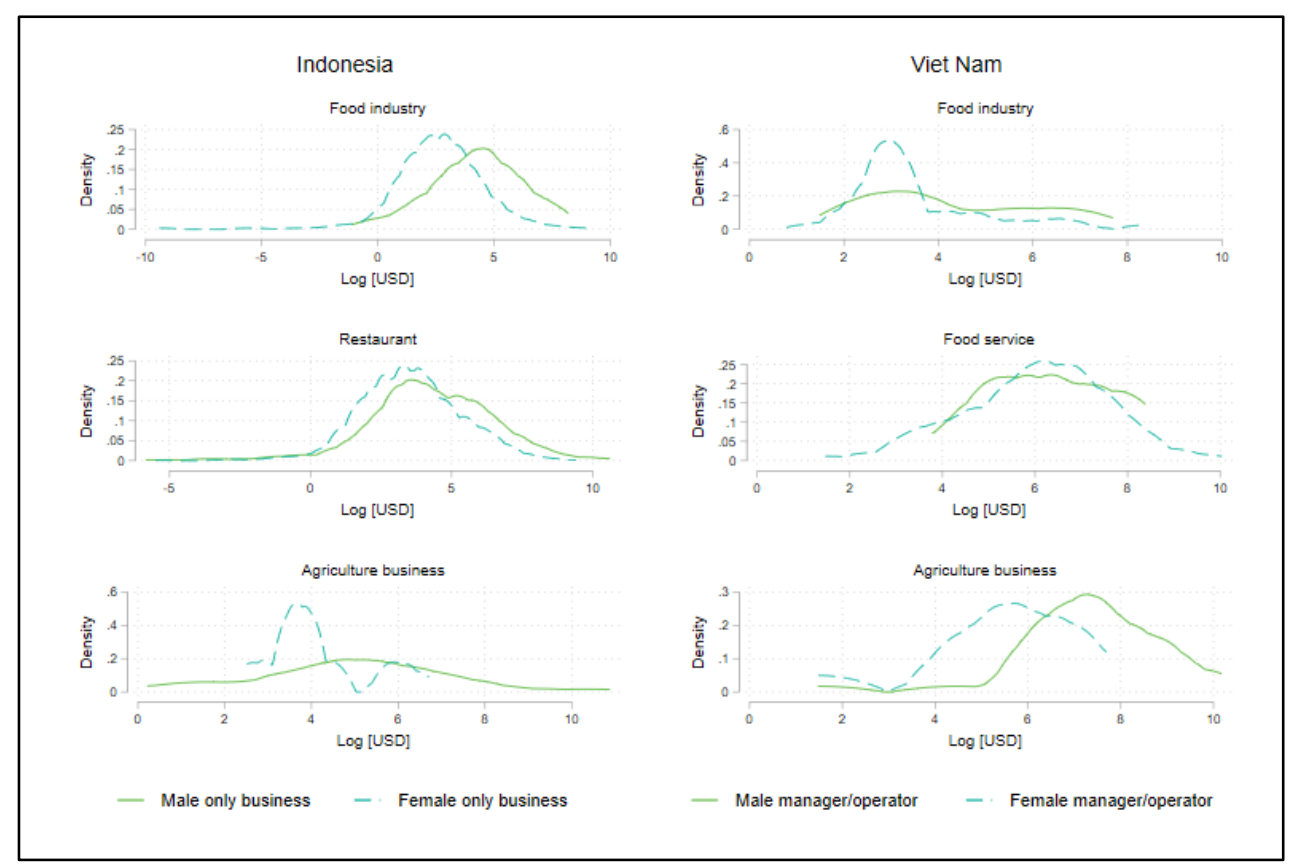

Another important distinction in financing for men's and women's businesses is the source. Table 4 shows the source of startup capital by gender for each country. Again, we observe a sharp contrast between men and women. In both countries, women are more likely to rely on savings, self-financing, or within family resources, whereas men are more likely to report borrowing either from banks or individuals outside the family. The difference is particularly pronounced in Viet Nam. 


\section{Table 4: Sources of Start-Up Capital by Gender, Indonesia and Viet Nam}

\begin{tabular}{|c|c|c|c|c|}
\hline & \multicolumn{4}{|c|}{ Indonesia } \\
\hline & \multicolumn{2}{|c|}{ Male businesses } & \multicolumn{2}{|c|}{ Female businesses } \\
\hline & Average & $\mathrm{N}$ & Average & $\mathrm{N}$ \\
\hline Capital source: Savings & 0.56 & 2395 & 0.62 & 2324 \\
\hline Capital source: Family & 0.23 & 2395 & 0.25 & 2324 \\
\hline Capital source: Individuals not in family & 0.06 & 2395 & 0.02 & 2324 \\
\hline Capital source: Bank & 0.1 & 2395 & 0.06 & 2324 \\
\hline \multirow[t]{4}{*}{ Capital source: Other } & 0.03 & 2395 & 0.03 & 2324 \\
\hline & \multicolumn{4}{|c|}{ Viet Nam } \\
\hline & \multicolumn{2}{|c|}{ Male businesses } & \multicolumn{2}{|c|}{ Female businesses } \\
\hline & Average & $\mathrm{N}$ & Average & $\mathrm{N}$ \\
\hline Source: Only self-finance & 0.53 & 386 & 0.81 & 390 \\
\hline Source: Only self-finance & 0.53 & 386 & 0.81 & 390 \\
\hline Source: Only borrowing & 0.06 & 386 & 0.02 & 390 \\
\hline
\end{tabular}

Sources: IFLS (2015) for Indonesia and VARHS (2016) for Viet Nam.

These differences in funding source are consistent with the lower volumes of start-up capital for women relative to men, assuming that banks and external family members are likely to have greater volumes of capital available than can be mobilized through saving or within families. However, even within these sources of capital, gender differences persist. Figure 3 shows that startup capital from savings, borrowing, and banks is significantly lower for women than for men. 
Figure 3: Average start-up capital of agrifood businesses, by gender and source of finance, Indonesia and Viet Nam

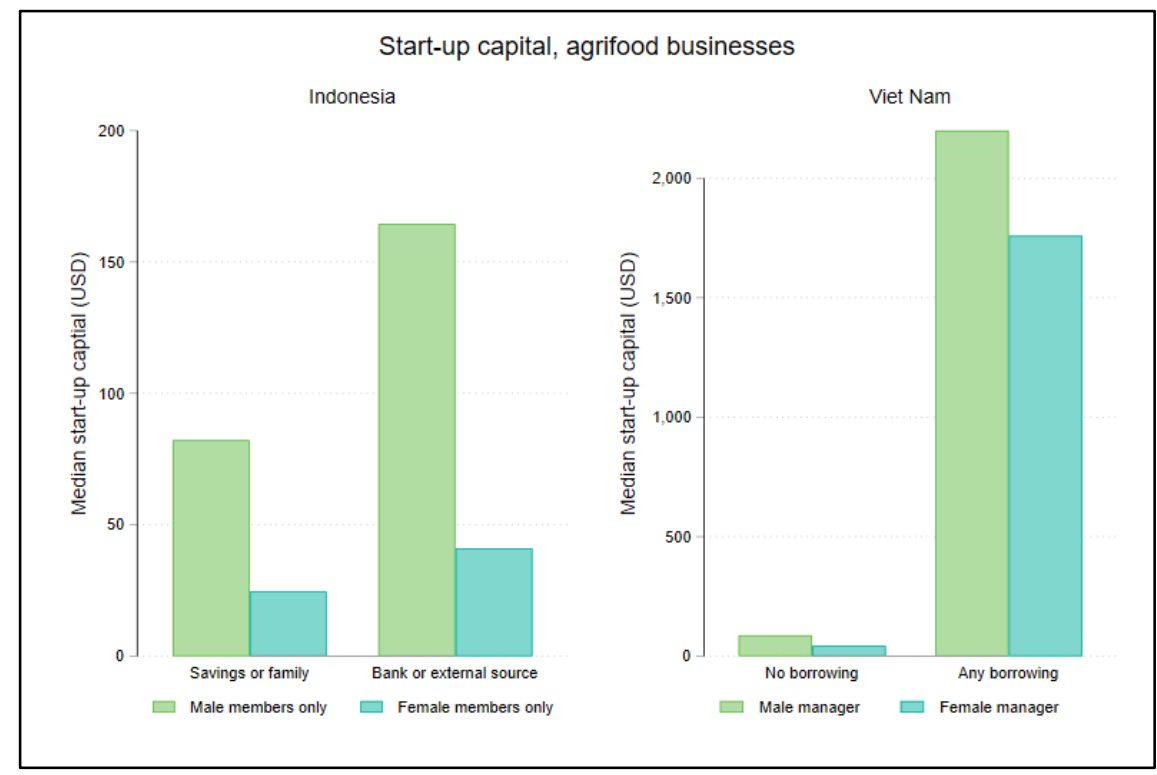

Expansion of the agrifood system is creating new economic opportunities. However, use of financing does not appear to be equitable for men and women. Women are overrepresented in less capitalized industries and leverage less start-up capital relative to men within these sectors, while relying more heavily on savings and within-family resource mobilization. If these differences in finance usage reflect differences in opportunities, they may constitute meaningful barriers to business investment and expansion for women.

That said, to better understand constraints and opportunities faced by men and women in starting, managing, and growing businesses within the agri-food system, it is clear more sex-disaggregated data is necessary on financial access generally and on agri-food system businesses specifically. Improved data would help researchers understand what types of constraints exist on men's and women's ability of obtain capital, and whether it is plausible that the operation of women's businesses is negatively affected by limited property rights, control of business finances, or constrained labor or managerial ability due to household responsibilities. An important, open question from this analysis is whether women are kept from profitable business opportunities because they cannot access formal credit, or if their lower use of credit is a reflection of other constraints they face in their businesses and lives. With better descriptive data, researchers can design and implement causal research that can help develop evidence-based policy guidance to alleviate constraints in the agri-food sector.

\section{ABOUT THE AUTHORS}

Alan de Brauw is a Senior Research Fellow, Kate Ambler and Sylvan Herskowitz are Research Fellows, and Mike Murphy is a Senior Research Analyst; all at the International Food Policy Research Institute. 


\title{
ACKNOWLEDGMENTS
}

The authors would like to thank Rodd Dyer, Howard Hall, Nguyen Le Hoa, Tom Moyes, Sahat Pasaribu, Bambang Sayaka, Russell Toth, and Truong Thi Thu Trang for collaboration and conversations about agricultural finance in both countries that have helped develop the ideas in this project note.

\section{REFERENCES}

Shakhovskoy, M., \& Wendle, J. (2013). Inflection Point: Unlocking growth in the era of farmer finance. Washington, DC: The Initiative for Smallholder Finance.

\section{ENDNOTES}

\begin{abstract}
${ }^{1}$ See https://voxdev.org/topic/firms-trade/helping-microenterprises-grow-what-works-and-what-doesn-t for a brief review of microenterprise research suggesting widespread credit constraints as well as the presence of additional factors impacting female owned/managed enterprises.

2 This gap is particularly striking given that the Indonesian sample includes both urban and rural respondents while the Vietnamese sample is exclusively rural.

${ }^{3}$ Jointly owned businesses in the Indonesia sample are excluded to ease the comparison.
\end{abstract}

This work was undertaken as part of the CGIAR Research Program on Policies, Institutions, and Markets (PIM) led by the International Food Policy Research Institute (IFPRI). Funding support for this study was provided by the Australian Centre for International Agricultural Research and the CGIAR Research Program on Policies, Institutions, and Markets. This note has not gone through a peer-review procedure. The opinions expressed here belong to the authors, and do not necessarily reflect those of PIM, IFPRI, or CGIAR.

\section{INTERNATIONAL FOOD POLICY RESEARCH INSTITUTE \\ A world free of hunger and malnutrition}

